\title{
Calcium cycling proteins in heart failure, cardiomyopathy and arrhythmias
}

\author{
Susumu Minamisawa ${ }^{1,4}$, Yoji Sato ${ }^{2}$ \\ and Myeong-Chan $\mathrm{Cho}^{3}$ \\ ${ }^{1}$ Department of Physiology \\ Yokohama City University School of Medicine \\ Yokohama 236-0004, Japan \\ ${ }^{2}$ Division of Cellular and Gene Therapy Products \\ National Institute of Health Sciences \\ Tokyo 158-8501, Japan \\ ${ }^{3}$ Department of Cardiology \\ College of Medicine, Chungbuk National University \\ Cheongju 361-711, Korea \\ ${ }^{4}$ Corresponding author: Tel, 81-45-787-2575; \\ Fax, 81-45-788-1470; \\ E-mail, sminamis@med.yokohama-cu.ac.jp
}

Accepted 11 June 2004

Abbreviations: $A R V D$, arrhythmogenic right ventricular cardiomyopathy; CPVT, catecholaminergic polymorphic ventricular tachycardia; CSQ2, cardiac calsequestrin; EC, excitation-contraction; FKBP, a FK506 binding protein; iRNA, Inhibitory RNA; ICa, the $\mathrm{Ca}^{2+}$ currents; JP2, junctophilin type 2; LCC, L-type $\mathrm{Ca}^{2+}$ channels; mAKAP, PKA anchoring protein; PKA, protein kinase A; PLN, phospholamban; RyR2, the cardiac ryanodine receptor; SAR, sarcalumenin; SERCA2a, the SR calcium ATPase 2a; SLN, sarcolipin; SR, sarcoplasmic reticulum

\begin{abstract}
A growing body of evidence, including studies using genetically engineered mouse models, has shown that $\mathrm{Ca}^{2+}$ cycling and $\mathrm{Ca}^{2+}$-dependent signaling pathways play a pivotal role in cardiac hypertrophy and heart failure. In addition, recent studies identified that mutations of the genes encoding sarcoplasmic reticulum (SR) proteins cause human cardiomyopathies and lethal ventricular arrhythmias. The regulation of $\mathrm{Ca}^{2+}$ homeostasis via the SR proteins may have potential therapeutic value for heart diseases such as cardiomyopathy, heart failure and arrhythmias.
\end{abstract}

Keywords: calcium ATPase; calcium homeostasis; cardiomyopathy; heart failure; phospholamban; ryanodine receptor; sarcoplasmic reticulum

\section{Introduction}

Calcium is not only indispensable for normal muscle contraction and relaxation but also important as a second messenger of various signaling pathways in the heart. A growing body of evidence has shown that $\mathrm{Ca}^{2+}$ homeostasis and $\mathrm{Ca}^{2+}$-dependent signaling pathways play a pivotal role in the development of cardiac hypertrophy, heart failure and arrhythmias. In this regard, two issues regarding the role of $\mathrm{Ca}^{2+}$ in the heart are attracting considerable attention. One is the discovery of $\mathrm{Ca}^{2+} / \mathrm{calmodulin}-$ dependent calcineurin signaling pathway in cardiac hypertrophy (Olson and Williams, 2000; Wilkins and Molkentin, 2002) and the other is to identify the critical role of cardiac $\mathrm{Ca}^{2+}$ cycling in cardiomyopathy, heart failure and arrhythmias (Chien, 2000; Houser et al., 2000; Scoote and Williams, 2002). In this review, we focus on the latter topic, especially on $\mathrm{Ca}^{2+}$ cycling proteins in the sarcoplasmic reticulum (SR).

\section{The regulation of $\mathrm{Ca}^{2+}$ release and uptake via the cardiac sarcoplasmic reticulum}

Periodic changes in $\mathrm{Ca}^{2+}$ concentration in cardiomyocytes are essential for cardiac contraction and relaxation, and the intracellular $\mathrm{Ca}^{2+}$ concentration is integrally regulated by proteins associated with the $\mathrm{SR}$, an extensive intracellular membrane system. The SR consists of lipid bilayer organelle that surrounds each myofibril. In response to membrane depolarization, a small amount of extracellular $\mathrm{Ca}^{2+}$ enters the cardiomyocyte through the L-type $\mathrm{Ca}^{2+}$ channels. The $\mathrm{Ca}^{2+}$ influx triggers the release of $\mathrm{Ca}^{2+}$ from the SR into the cytosol through the cardiac ryanodine receptor (RyR2), initiating cardiac contraction. This event is known as $\mathrm{Ca}^{2+}$ induced- $\mathrm{Ca}^{2+}$ release. The relaxation is predominantly mediated by $\mathrm{Ca}^{2+}$ sequestration from the cytosol into the SR lumen via the SR calcium ATPase 2a (SERCA2a). The activity of the RyR2 and SERCA2a are known to be under fine-tuning by their intrinsic regulatory domains and associated SR proteins.

The RyR2 forms homotetramers consisting of 4 monomeric subunits, each of about $565-\mathrm{kDa}$ to produce a bona fide ion channel. The subunit contains a high-conductance $\mathrm{Ca}^{2+}$-selective pore, $\mathrm{Ca}^{2+}$ activation and inactivation sites, several phosphoryla- 
tion sites, and multiple binding sites for a myriad of endogenous regulators including ATP, $\mathrm{Mg}^{2+}$, and calmodulin. The RyR2 also forms a macromolecular complex by protein-protein interactions, including protein kinase $A(P K A)$ and its anchoring protein (mAKAP), the protein phosphatases PP1 and PP2A, sorcin, calmodulin, a FK506 binding protein (FKBP12.6), and other proteins in the cytosol (Marks et al., 2002a). In the luminal region of junctional SR membrane, the RyR2 is also associated with cardiac calsequestrin (CSQ), triadin, junctin, and junctate, which are all required for appropriate regulation of the $\mathrm{Ca}^{2+}$ release from the RyR2 (Muller et al., 2002). Although CAMP-dependent PKA signal pathway plays the most important role in the regulation of the RyR-mediated $\mathrm{Ca}^{2+}$ release, the function of the RyR2 is regulated by many other factors, including several regulatory domains and protein-protein interactions with many molecules.

$\mathrm{CSQ}$ is a $55-\mathrm{kDa}$ high capacity, moderate affinity $\mathrm{Ca}^{2+}$-binding protein localized to the lumen of the junctional SR in cardiac muscle. CSQ forms a dense matrix in the SR lumen, where the protein appears to be physically connected to the RyR2 by anchoring strands. Biochemical evidence suggests that CSQ actively participates in muscle contraction by regulating the amount of luminal $\mathrm{Ca}^{2+}$ store (Sitsapesan and Williams, 1997). This regulatory effect of CSQ may be mediated by CSQ-anchoring proteins such as triadin and junctin (Zhang et al., 1997). Triadin was first identified as a $95-\mathrm{kDa}$ protein in skeletal muscle junctional SR membrane (Caswell et al., 1991) and subsequently three cardiac triadin isoforms (triadin 1 , 2 and 3 ) were cloned. Junctin was originally identified

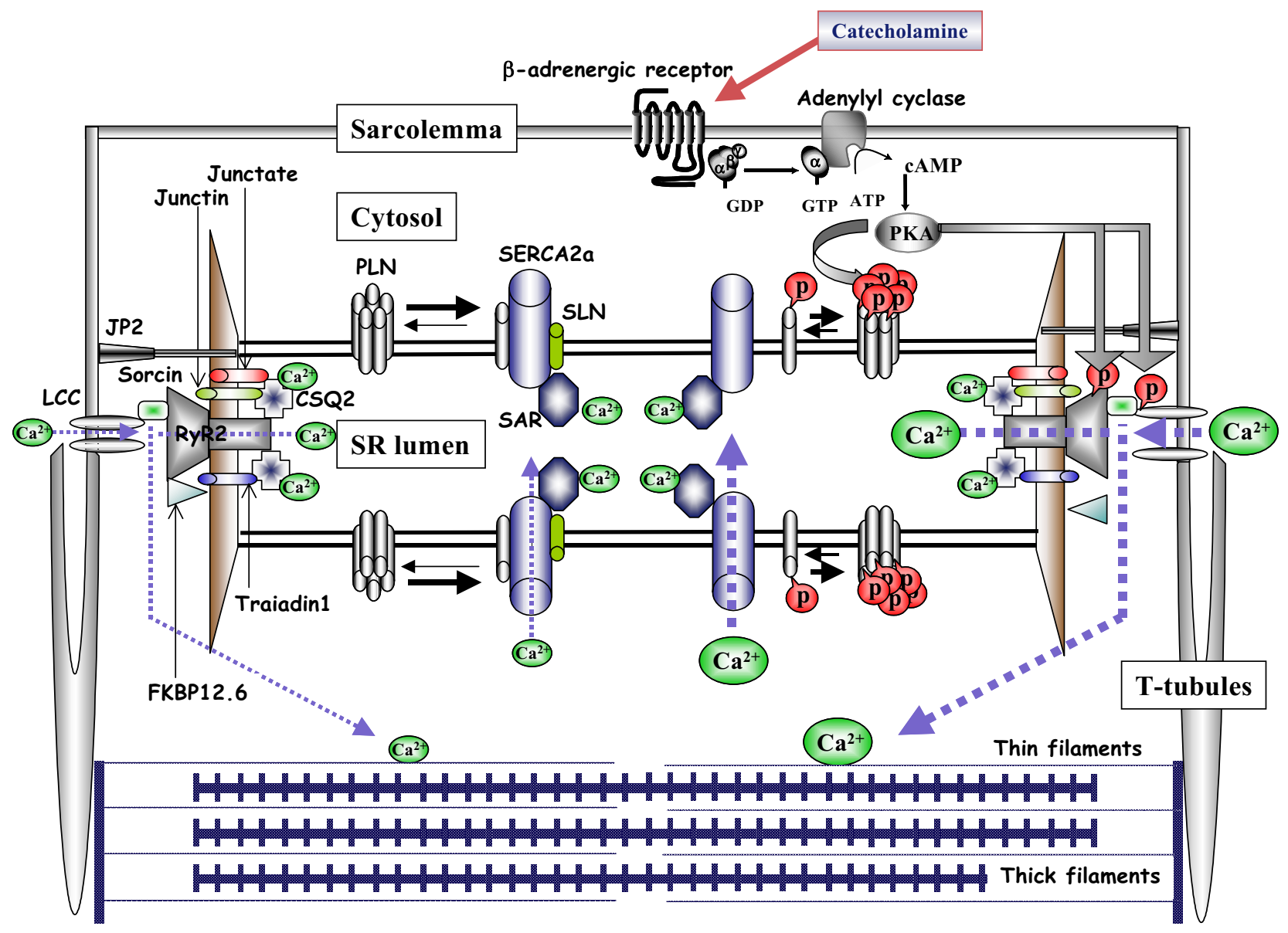

Figure 1. Major cardiac SR proteins involved in $\mathrm{Ca}^{2+}$ cycling in cardiomyocytes. The $\mathrm{Ca}^{2+}$ movement was demonstrated by blue broken lines. The right-sided panel shows the enhanced $\mathrm{Ca}^{2+}$ release and uptake by $\beta$-adrenergic stimulation via cAMP-dependent PKA signal pathway. PKA phosphorylates L-type $\mathrm{Ca}^{2+}$ channels (LCC), the cardiac ryanodine receptor (RyR2) and phospholamban (PLN). The phosphorylated RyR2 is dissociated from FKBP12.6, resulting in pronounced channel open probability. Phosphorylated PLN relieves its inhibition on SERCA2a activity, resulting in an increase in $\mathrm{Ca}^{2+}$ uptake into the SR. Junctophilin type 2 (JP2) is a membrane spanning protein between the sarcolemmal membrane and the SR. Sorcin is a penta-EF hand $\mathrm{Ca}^{2+}$-binding protein that binds directly to both RyR2 and the LCC. The RyR2 is also associated with cardiac calsequestrin (CSQ2), triadin, junctin, and junctate. CSQ2 and sarcalumenin (SAR) are $\mathrm{Ca}^{2+}$-binding proteins localized in the junctional and longitudinal SR, respectively. Sarcolipin (SLN) that is expressed predominantly in the atria may inhibit SERCA2a activity. 
as a $26-\mathrm{kDa}$ major $\mathrm{CSQ}$-binding protein in cardiac and skeletal muscle junctional SR membranes (Jones et al., 1995). Although triadin and junctin are the products of different genes, they exhibit intriguing structural and amino acid sequence similarities and play an important role in the regulation of $\mathrm{Ca}^{2+}$ release from the RyR2. Junctate, an alternative splicing form of the same gene generating junctin and aspartyl $\beta$-hydroxylase, is a newly identified $33-\mathrm{kDa} \mathrm{Ca}^{2+}$ binding protein in the integral SR membrane and three cardiac isoforms (junctate 1,2 and 3 ) were cloned from the mouse heart (Treves et al., 2000; Hong et al., 2001).

Crosstalk between L-type $\mathrm{Ca}^{2+}$ channels on the sarcolemmal membrane and the RyR2 on the SR is a fundamental feature of excitation-contraction (EC) coupling in the heart. Junctophilin type 2 (JP2), a cardiac isoform of JP family, has been recently identified as a membrane spanning protein that contributes to the formation of the junctional membrane complexes between the sarcolemmal membrane and the SR (Takeshima et al., 2000). JP2 is an essential component for the stabilization of the junctional membrane complexes and may play an important role in maintaining normal functional coupling of $\mathrm{Ca}^{2+}$ induced $-\mathrm{Ca}^{2+}$ release.

SERCA2a, a cardiac and slow-twitch skeletal muscle isoform of SERCA family that belongs to P-type ATPases, is the primary regulator of the rate of $\mathrm{Ca}^{2+}$ re-uptake during relaxation in the heart (Periasamy and Huke, 2001). The activity of SERCA2a is mainly regulated by its endogenous inhibitor, phospholamban (PLN). PLN, a 52 amino acid SR transmembrane phosphoprotein, inhibits $\mathrm{Ca}^{2+}$ uptake to interact with SERCA2a at their cytoplasmic and transmembrane domains. Phosphorylated PLN relieves its inhibition on SERCA2a activity, resulting in an increase in $\mathrm{Ca}^{2+}$ uptake into the SR (Frank and Kranias, 2000).

Sarcolipin has been identified as a counterpart of PLN in skeletal muscle (Odermatt et al., 1998). The expression of mouse sarcolipin mRNA, however, was most abundant in the atria and was undetectable in the ventricles, indicating an atrial chamber-specific expression pattern in the heart (Minamisawa et al., 2003b). Atrial chamber-specific expression of sarcolipin mRNA was increased during development and was down-regulated in the atria of hypertrophic heart. In human, sarcolipin mRNA was also expressed in the atria, but not detected in the ventricles. Therefore, sarcolipin is likely to be an atrial chamber-specific regulator of $\mathrm{Ca}^{2+}$ cycling in the heart. It is intriguing to know whether sarcolipin plays an important role in the atrium-specific cardiac disorders such as atrial fibrillation.

Sarcalumenin is a $\mathrm{Ca}^{2+}$-binding protein localized in the longitudinal SR. Sarcalumenin isoforms are generated as 160 - and $53-\mathrm{kDa}$ glycoproteins by the alternative splicing of the primary transcript derived from its gene, and are specifically expressed in skeletal and cardiac muscle cells (Leberer et al., 1990). The amino-terminal half of the $160-\mathrm{kDa}$ isoform is characterized by the juxtapositions of negatively charged residues resembling to that of CSQ. Although several studies have suggested that sarcalumenin works as a $\mathrm{Ca}^{2+}$-buffering protein like $\mathrm{CSQ}$ and regulates SERCA activity (Martin, 1990), the physiological role of sarcalumenin remains largely unknown at the present.

The functional relevance between $\beta$-adrenergic sysytem/cAMP-dependent PKA signal pathway and $\mathrm{Ca}^{2+}$ cycling in the heart has been warranted (Figure 1). cAMP-dependent PKA signal pathway plays a pivotal role in the regulation of $\mathrm{Ca}^{2+}$ release and uptake in the SR. Marx et al. demonstrated that the phosphorylated RyR2 by PKA is dissociated from FKBP12.6, resulting in pronounced channel open probability. Furthermore, the hyperphosphorylated RyR2 increased $S R \mathrm{Ca}^{2+}$ leak from the $\mathrm{SR}$ in patients with heart failure (Marx et al., 2000). Yano et al. also found that the binding of FKBP12.6 to the RyR2 was decreased in pacing-induced heart failure when compared with normal hearts (Yano et al., 2000). As to $\mathrm{Ca}^{2+}$ uptake into the $\mathrm{SR}$, phosphorylation at PLN serine- 16 by PKA is the predominant event leading to a proportional increase in the rate of $\mathrm{Ca}^{2+}$ uptake and accelerates ventricular relaxation (Colyer, 1998). PLN is considered to be mostly responsible for the effects of $\beta$-adrenergic stimulation on cardiac contractility and relaxation, since PLN deficient mice display the maximal contraction without $\beta$-adrenergic stimulation (Luo et al., 1994). A decrease in PLN phosphorylation has been demonstrated in patients or animal models of heart failure, resulting in a decrease in $\mathrm{Ca}^{2+}$ uptake into the SR (Schmidt et al., 1999; Sande et al., 2002). Therefore, abnormal $\beta$-adrenergic/cAMP-dependent PKA signal pathway induces the imbalance of $\mathrm{Ca}^{2+}$ release and uptake in the $S R$, resulting in the reduced $\mathrm{Ca}^{2+}$ content in the $\mathrm{SR}$. This is a central physiological hallmark of a number of animal models of heart failure, as well as in human failing hearts.

\section{Genetically engineered animal models}

Genetically engineered mice, such as transgenic and knockout mice, have proved to be extremely useful for understanding the regulation of many molecules involved in $\mathrm{EC}$ coupling and $\mathrm{Ca}^{2+}$ cycling in the heart, and have given strong insights for pathophysiological roles of the SR proteins (Kadambi and Kranias, 1998; Dillmann, 1999). 
Table 1. Genetically engineered animal model.

\begin{tabular}{|c|c|c|}
\hline Transgene & Cardiac phenotypes & References \\
\hline RyR-2 KO & $\begin{array}{l}\text { Embryonic lethal with morphological abnormalities in the } \\
\text { heart tube } \\
\text { Large vacuolate SR and structurally abnormal mitochondria }\end{array}$ & Takeshima, 1998 EMBO J \\
\hline FKBP12 KO & $\begin{array}{l}\text { Embryonic lethal with severe dilated cardiomyopathy and } \\
\text { ventricular septal defects } \\
\text { Noncompaction of left ventricular myocardium }\end{array}$ & Shou,1998 Nature \\
\hline FKBP12.6 KO & $\begin{array}{l}\text { Cardiac hypertrophy in the male but not in the female } \\
\text { Loss of myofibril organization } \\
\text { Exercise-induced vetricular tachycardia }\end{array}$ & $\begin{array}{l}\text { Xin,2002 Nature } \\
\text { Wehrens, } 2003 \text { Cell }\end{array}$ \\
\hline Sorcin TG & $\begin{array}{l}\text { Impaired contraction and relaxation without overt cardiac } \\
\text { hypertrophy }\end{array}$ & Meyers, $2003 \mathrm{~J}$ Biol Chem \\
\hline Junctin TG & $\begin{array}{l}\text { Generalized cardiomegaly with systolic dysfunction } \\
\text { Bradycardia and atrial fibrillation } \\
\text { Increased fibrosis }\end{array}$ & $\begin{array}{l}\text { Zhang, } 2001 \mathrm{~J} \text { Mol Cell Cardiol } \\
\text { Hong, 2002 FASEB J } \\
\text { Kirchhefer, } 2003 \text { Cardiovas Res }\end{array}$ \\
\hline Triadin $1 \mathrm{TG}$ & Cardiac hypertrophy with impaired contractility and relaxation & Kirchhefer, $2001 \mathrm{~J}$ Biol Chem \\
\hline Junctate $1 \mathrm{TG}$ & $\begin{array}{l}\text { Dilated cardiomyopathy with severe systolic dysfunction } \\
\text { Bradycardia with various arrhythmias }\end{array}$ & Cho, $2003 \mathrm{~J} \mathrm{Am} \mathrm{Coll} \mathrm{Cardiol}$ \\
\hline CSQ2 TG & Cardiac hypertrophy with systolic dysfunction & $\begin{array}{l}\text { Sato, } 1998 \text { J Biol Chem } \\
\text { Cho, } 1999 \text { J Biol Chem }\end{array}$ \\
\hline SERCA2 KO & $\begin{array}{l}\text { Embryonic lethal in homozygous mice } \\
\text { Impaired contraction and relaxation in heterozygous mice }\end{array}$ & $\begin{array}{l}\text { Periasamy, } 1999 \mathrm{~J} \text { Biol Chem } \\
\mathrm{Ji}, 2000 \mathrm{~J} \text { Biol Chem }\end{array}$ \\
\hline SERCA2a KO & $\begin{array}{l}\text { High incidence of perineonatal mortality and cardiac } \\
\text { malformations } \\
\text { Mild cardiac hypertrophy with impaired cardiac contractility } \\
\text { and relaxation }\end{array}$ & Ver Heyen, 2001 Cir Res \\
\hline SERCA2a TG & Enhanced cardiac contractility and relaxation & $\begin{array}{l}\text { He, } 1997 \mathrm{~J} \text { Clin Invest } \\
\text { Baker, } 1998 \text { Cir Res }\end{array}$ \\
\hline SERCA1 TG & Enhanced cardiac contractility and relaxation & Loukianov, 1998 Cir Res \\
\hline SERCA2b TG & Enhanced cardiac contractility and relaxation & Greene, $2000 \mathrm{~J}$ Biol Chem \\
\hline$\underset{\text { TG }}{\operatorname{mutant} \text { SERCA2a }}$ & $\begin{array}{l}\text { K397/400E, lack of a functional association with PLN } \\
\text { Enhanced cardiac contractility and relaxation }\end{array}$ & Nakayama, 2003 FASEB J \\
\hline PLN KO & Enhanced cardiac contractility and relaxation & Luo, 1994 Cir Res \\
\hline PLN TG & $\begin{array}{l}\text { Impaired cardiac contractility and relaxation without overt } \\
\text { cardiac remodeling (2-fold overexpression) } \\
\text { Heart failure with aging (4-fold overexpression) }\end{array}$ & $\begin{array}{l}\text { Kadambi, } 1996 \mathrm{~J} \text { Clin Invest } \\
\text { Dash, } 2001 \text { Circulation }\end{array}$ \\
\hline \multicolumn{3}{|l|}{ mutant PLN TG } \\
\hline $\mathrm{C} 41 \mathrm{~F}$ & $\begin{array}{l}\text { Monomeric form of PLN; Less pronounced inhibitory effect } \\
\text { when compared with wild-type PLN }\end{array}$ & Chu, 1998 Cir Res \\
\hline S16A, T17A & $\begin{array}{l}\text { Non-phosphorylatable form of PLN; Maximal inhibition of } \\
\text { SERCA2a activity }\end{array}$ & Brittsan, $2000 \mathrm{~J}$ Biol Chem \\
\hline L37A, I40A & $\begin{array}{l}\text { Monomeric, dominant-acting, superinhibitory PLN; Impaied } \\
\text { contractility with cardiac hypertrophy }\end{array}$ & Zvaritch, $2000 \mathrm{~J}$ Biol Chem \\
\hline V49G & $\begin{array}{l}\text { A superinhibitor of SERCA2a affinity for } \mathrm{Ca} 2+\text {; Impaired } \\
\text { cardiac function and heart failure }\end{array}$ & Haghighi, $2001 \mathrm{~J}$ Biol Chem \\
\hline N27A & $\begin{array}{l}\text { A PLN hinge domain mutant; Impaired cardiac function and } \\
\text { heart failure }\end{array}$ & Schmidt, 2002 Cardiovasc Res \\
\hline S16E & $\begin{array}{l}\text { A pseudophosphorylated PLN; Enhanced cardiac contractility } \\
\text { and relaxation }\end{array}$ & Hoshijima, 2002 Nat Med \\
\hline $\mathrm{R} 9 \mathrm{C}$ & $\begin{array}{l}\text { Blockade of PKA-mediated PLN phosphorylation; Impaired } \\
\text { cardiac function and heart failure }\end{array}$ & Schmidt, 2003 Science \\
\hline
\end{tabular}


Knockout mice lacking RyR2 die at approximately embryonic day 10 with morphological abnormalities in the heart tube. Prior to embryonic death, large vacuolate $S R$ and structurally abnormal mitochondria began to develop in the knockout cardiomyocytes, and the vacuolate SR appeared to contain high concentrations of $\mathrm{Ca}^{2+}$. This result suggests that RyR2 is absolutely required for cellular $\mathrm{Ca}^{2+}$ homeostasis most probably as a major $\mathrm{Ca}^{2+}$ release channel to maintain the developing SR (Takeshima et al., 1998). Alterations in RyR2 accessory proteins are also associated with pathogenesis in the heart. Ablation of FKBP12.6 gene caused cardiac hypertrophy in male mice, but not in female, despite the similar dysregulation of $\mathrm{Ca}^{2+}$ release in male and female knockout mice (Xin et al., 2002). FKBP12.6-null mice consistently exhibited exercise-induced cardiac ventricular arrhythmias that cause sudden cardiac death. (Wehrens et al., 2003). Since FKBP 12.6 stabilizes RyR2 channel activity and prevents aberrant activation of RyR2 during the resting phase of the cardiac cycle, this data suggests that unstable RyR2 channel can induce life-threatening arrhythmias. Although FKBP12 is predominantly associated with skeletal RyR (RyR1), FKBP12-deficient mice displayed severe dilated cardiomyopathy and ventricular septal defects without abnormality in skeletal muscle (Shou et al., 1998).

Sorcin is a penta-EF hand $\mathrm{Ca}^{2+}$-binding protein that binds directly to both RyR2 and the L-type $\mathrm{Ca}^{2+}$ channel. The transgenic mice exhibited no cardiac hypertrophy and no change in expression of other calcium regulatory proteins. However, significant reductions in global indices of contraction and relaxation were observed in the transgenic hearts. In addition, $\mathrm{Ca}^{2+}$ transient amplitudes were significantly depressed and the $\mathrm{Ca}^{2+}$ currents $\left(I_{\mathrm{Ca}}\right)$ inactivation rate of the L-type $\mathrm{Ca}^{2+}$ channel was significantly accelerated in transgenic myocytes (Meyers et al., 2003).

Overexpression of the junctin under the control of $\alpha$-myosin heavy chain promoter caused bi-atrial and bi-ventricular enlargements, impaired LV systolic function, bradycardia, atrial fibrillation, and increased fibrosis (Zhang et al., 2001; Hong et al., 2002; Kirchhefer et al., 2003). Transgenic mice overexpressing triadin 1 in atria and ventricles demonstrated cardiac hypertrophy and impaired contractility and relaxation (Kirchhefer et al., 2001). Cardiac-specific overexpression of junctate 1 resulted in dilated cardiomyopathy with severely depressed LV systolic function and various arrhythmias such as atrial fibrillation, ventricular premature beats and sinus pause. The reduced $\mathrm{SR} \mathrm{Ca}^{2+}$ content, enhanced L-type $\mathrm{Ca}^{2+}$ current density, and the prolonged action potential duration may account for the bradycardia in the junctate 1 transgenic heart (Cho et al., 2003). Thus, the transgenic mice with cardiac-specific overexpression of triadin 1, junctin and junctate 1 show distinct cardiac phenotypes, suggesting that these junctional SR transmembrane proteins are of functional relevance for the regulation of the SR $\mathrm{Ca}^{2+}$ release in the heart.

To elucidate the physiological significance of cardiac CSQ (CSQ2) in the cardiac excitation-contraction coupling, two independent lines of transgenic mice overexpressing CSQ2 in the heart have been generated (Jones et al., 1998; Sato et al., 1998). Although cardiac-targeted overexpression of CSQ2 results in a marked increase in $\mathrm{SR} \mathrm{Ca}^{2+}$ storage in the both models, $\mathrm{SR} \mathrm{Ca}^{2+}$ release was impaired upon depolarization, leading to depressed contractile parameters and cardiac hypertrophy. Transition from concentric LV hypertrophy to overt heart failure was clearly demonstrated and defective $\beta$-adrenergic receptor signaling preceded the development of dilated cardiomyopathy (Cho et al., 1999). These findings suggest that chronic suppression of $\mathrm{Ca}^{2+}$ release caused by overexpression of CSQ2 or the excess amount of CSQ2 per se also initiate a cascade of molecular events that activates the program of cardiac hypertrophy and/or heart failure. In contrast, no phenotypic feature of heart failure was observed up to 17 months of age in ventricles of the model of Sato et al., which expresses higher amount of CSQ2 in the myocardium, suggesting that endogenous traits of the mouse strains also influence the outcomes (Sato et al., 2003).

The genetic ablation of JP2 in mice caused wider gap size of the junctional membrane complexes and deficient $\left[\mathrm{Ca}^{2+}\right]_{i}$ transients in cardiomyocytes, resulting in embryonic lethality (Takeshima et al., 2000). These findings indicate that JP2 is essential to form normal junctional membrane complexes and efficient $\mathrm{Ca}^{2+}$ induced $-\mathrm{Ca}^{2+}$ release in the heart. The expression of JP2 was up-regulated during normal development and was down-regulated in a hypertrophic or dilated cardiomyopathic mouse model (Minamisawa et al., unpublished data). JP type 1 (JP1) is a skeletal muscle type of JP isoforms. JP1 knockout mice died shortly after birth and exhibited deficiency of triad junctions and contraction in skeletal muscles (Ito et al., 2001). Transgenic mice overexpressing JP1 exibted abnormal junctional membranes, in which the T-tubules were rolled up with the SR membranes. However, authentic triad formation was not induced by JP1 overexpression in cardiac myocytes, suggesting that ectopic JP1 expression cannot convert the diad to the triad in cardiac myocytes (Komazaki et al., 2003).

Two independent groups generated transgenic mice overexpressing SERCA2a in the heart. The increase in SERCA2a expression resulted in myocardial contractility and relaxation by increasing $\mathrm{SR} \mathrm{Ca}^{2+}$ transport (He et al., 1997; Baker et al., 1998). Transgenic 
mice overexpressing a high calcium affinity SERCA2a mutant (K397/400E), lacking a functional association with PLN, were also generated. The transgenic mouse hearts showed increased contraction and relaxation, with increases in the amplitude of $\mathrm{Ca}^{2+}$ transient and rapid $\mathrm{Ca}^{2+}$ decay (Nakayama et al., 2003). Moreover, transgenic mice overexpressing the fast-twitch skeletal muscle type of SERCA (SERCA1a) (Loukianov et al., 1998) or SERCA2b (Greene et al., 2000 ) in a heart-specific manner were also generated. Both mice demonstrated enhanced myocardial contractility and increased $\mathrm{Ca}^{2+}$ transport function, indicting that both SERCA isoforms can substitute for SERCA2a in vivo.

Complete ablation of SERCA2 (both SERCA2a and $2 \mathrm{~b})$ resulted in embryonic lethality (Periasamy et al., 1999). Heterozygous mutant hearts that expressed $65 \%$ of the protein levels of SERCA2 compared with wild-types showed impaired cardiac contractility and relaxation (Ji et al., 2000). When SERCA2a gene was specifically ablated, homozygous mutant hearts expressed only SERCA2b of which the protein levels were reduced to $40 \%$ of total SERCA2 in wild-type mice. SERCA2a deficiency led to increased incidence of perineonatal mortality and cardiac structural malformations as well as mild cardiac hypertrophy with impaired cardiac contractility and relaxation (Ver Heyen et al., 2001). This data indicates that SERCA2a is essential for normal cardiac development and function.

Transgenic mice expressed two-fold higher levels of PLN in the heart displayed impaired cardiac contractility and relaxation without any phenotypic alterations including heart-to-body mass ratio, cardiomyocyte size and morphology (Kadambi et al., 1996). However, transgenic mice overexpressing PLN at 4-fold normal levels exhibited the development of overt heart failure and a premature mortality with aging (Dash et al., 2001). To elucidate whether the site-specific mutations of PLN alter cardiac contractility and relaxation, more than 10 transgenic mice overexpressing various types of mutant PLN have been also generated (Chu et al., 1998; Brittsan et al., 2000; Zvaritch et al., 2000; Haghighi et al., 2001; Hoshijima et al., 2002; Schmidt et al., 2002; Schmitt et al., 2003). Among them, an increase in cardiac contractility and relaxation is detected only in the transgenic mice overexpressing a S16E peudo-phosphorylated PLN mutant (Hoshijima et al., 2002). Several transgenic mice exhibited impaired cardiac contractility and relaxation, resulting in cardiac remodeling such as cardiac hypertrophy (Zvaritch et al., 2000) and heart failure (Haghighi et al., 2001; Schmidt et al., 2002; Schmitt et al., 2003).

Mice heterozygous and homozygous for the PLNablated gene have been extensively evaluated by $\mathrm{Dr}$.
Kranias and her colleagues (Kadambi and Kranias, 1998). Reduction or ablation of PLN resulted in "supernormal" cardiac contraction and relaxation without any phenotypic alterations at the gross morphology or ultrastructural levels in mice (Luo et al., 1994).

\section{Human cardiomyopathy caused by genetic mutations in $\mathrm{Ca}^{2+}$ cycling molecules}

Cardiomyopathy is defined as a disease of the myocardium associated with cardiac dysfunction by either intrinsic/genetic disorders of myocardium, or extrinsic specific events like ischemia, pressure and volume overloads, abnormal metabolism, inflammation or toxic agents. Primary cardiomyopathy is a group of intrinsic disorders of the myocardium. To date, more than 20 genes have been identified as being responsible for cardiomyopathy. Despite the diverse etiologies, $\mathrm{Ca}^{2+}$ cycling defect is a physiological hallmark of all forms of cardiomyopathy. Therefore, the genes involved in $\mathrm{Ca}^{2+}$ cycling have been considered responsible for cardiomyopathy, and candidate gene approach has been employed in many laboratories.

In this regard, mutations in the RyR2 have been identified as the cause of arrhythmogenic right ventricular dysplasia (ARVD), a specific type of cardiomyopathy (Tiso et al., 2001). This is the first SR gene which causes cardiomyopathy. Mutations in the RyR2 also cause cathecholamine-induced polymorphic ventricular tachycardias (Marks et al., 2002b). These data indicate that RyR2 is responsible not only for cardiomyopathy and heart failure, but also for life-threatening arrhythmias.

Two independent groups have recently found that mutations of the PLN gene cause human dilated cardiomyopathy. One is a missense mutation at residue 9 (Arg $\rightarrow$ Cys) which is proposed to block PKA-mediated phosphorylation of PLN (Schmitt et al., 2003). The other is a nonsense mutation at residue 39 (Leu $\rightarrow$ stop) (Haghighi et al., 2003). In the former study, they generated Arg9Cys mutant PLN transgenic mice, in which PKA-mediated phosphorylation of PLN at serine 16 was blocked. The decay of $\mathrm{Ca}^{2+}$ transient was delayed in mutant myocytes, indicating impaired $\mathrm{Ca}^{2+}$ uptake. The mice recapitulated human heart failure. In the latter study, the heterozygous individuals with Leu39stop mutation exhibited hypertrophy without decreased contractile performance, and individuals homozygous displayed the diminished expression of PLN in the SR (null PLN) and dilated cardiomyopathy. The authors claimed that PLN is 
essential to maintain normal cardiac function in human, in contrast to mice in which PLN deficiency enhances cardiac contractility and relaxation without any adverse effects. These opposite results from different species have to be verified in detail, since, as we will discuss later, PLN is thought to be one of the prime targets for novel therapeutic invention of heart failure.

In addition, a single nucleotide transition, $-77 \mathrm{~A} \rightarrow \mathrm{G}$, in the PLN promoter region was found in a patient with late-onset type of hypertrophic cardiomyopathy (Minamisawa et al., 2003a). The mutation was found to increase PLN promoter activity using neonatal rat myocytes, suggesting that $-77 \mathrm{~A} \rightarrow \mathrm{G}$ mutation in the PLN promoter region increases the PLN expression in the heart. The mutation has not been found more than normal 300 individuals so far. Therefore, the mutation in the promoter region may play an important role in the development of hypertrophic cardiomyopathy in human. Since different mutations in several sarcomeric proteins such as $\beta$-myosin heavy chain and troponin $T$ cause dilated and hypertrophic cardiomyopathies (Seidman and Seidman, 2001), PLN is also likely to be associated with both dilated and hypertrophic cardiomyopathies. Here, the genes involved in $\mathrm{Ca}^{2+}$ cycling have become the real candidates responsible for cardiomyopathy. It should be intriguing to investigate mutations of other SR genes in patients with cardiomyopathy.

\section{Life-threatening ventricular arrhythmias caused by genetic mutations in $\mathrm{Ca}^{2+}$ cycling molecules}

A growing body of evidence indicates that mutations of RyR2 and CSQ2 cause catecholaminergic polymorphic ventricular tachycardia (CPVT) and ARVD2 (Lahat et al., 2001; Laitinen et al., 2001; Bauce et al., 2002; Postma et al., 2002; Priori et al., 2002; Lahat et al., 2003). Although the molecular mechanisms underlining the relation between genotypes and phenotypes remain unclear, one may assume that the greater amount of $\mathrm{Ca}^{2+}$ release from the mutant hearts may induce an elevated diastolic cytoplasmic $\mathrm{Ca}^{2+}$ during exercise- or catecholamine-induced stress, resulting in diastolic afterdepolarizations that can initiate fatal ventricular tachyarrhythmias. This increased $\mathrm{Ca}^{2+}$ release can be mediated by FKBP12.6. Recently, Wehrens et al demonstrated that a derivative of 1,4-benzothiazepine (JTV519) increased the affinity of FKBP12.6 for RyR2, which stabilized the closed state of RyR2 and prevented the $\mathrm{Ca}^{2+}$ leak that triggers arrhythmias (Wehrens et al., 2004). Thus, further investigation of mutations in other SR genes related to $\mathrm{Ca}^{2+}$ release such as FKBP12.6, triadin 1 and junctin will be warranted.

\section{The modulation of the SR proteins is potential therapeutic strategy for cardiom yopathy, heart failure, and arrhythmias}

Our current therapy for cardiomyopathy and heart failure is primarily palliative and is not biologically targeted because of poor understanding in stress pathways leading to the progression of cardiac muscle dysfunction. The lessons from animal studies and human genetics revealed, however, that a decrease in $\mathrm{Ca}^{2+}$ uptake due to reduced SERCA2a activity and an increase in $\mathrm{Ca}^{2+}$ leak from the SR due to instability of the RyR2 play an important role in the development of cardiomyopathy, heart failure and arrhythmias. Therefore, the restore of the SR function may be novel therapeutic strategy for these abnormalities.

Genetic approaches and pharmacological interventions, designed to increase SERCA2a activity or inhibit PLN function, may prove valuable in preventing or reversing the adverse physiological impairment in cardiomyopathy and heart failure. It may be a fundamental approach to increase SERCA2a activity by simply increasing the expression level of SERCA2a. This can be achieved through SERCA2a gene transfer. Dr. Hajjar's group demonstrated that muscle contractility and relaxation were restored by adenovirus-mediated SERCA2a gene transfer in an animal model of pressure overload (Miyamoto et al., 2000) as well as in cardiomyocytes from patients with heart failure (del Monte et al., 2001). They recently demonstrated that improving intracellular $\mathrm{Ca}^{2+}$ cycling by overexpression of SERCA2a restored contractile function and reduced ventricular arrhythmias during cardiac ischemia-reperfusion (del Monte et al., 2004).

Inhibition of PLN function or disruption of the interaction between PLN and SERCA2a is an alternative way to increase SERCA2a activity. Reduction of PLN expression by decreasing PLN transcription, or disrupting PLN mRNA stability seems to have promising value for pharmaceutical interventions to improve cardiac performance. Adenovirus-mediated antisense expression of PLN coding region resulted in the successful depression of PLN mRNA and protein and increased $\mathrm{Ca}^{2+}$ uptake in neonatal rat myocytes (He et al., 1999; Eizema et al., 2000). Inhibitory RNA (iRNA) for PLN mRNA can be an alternate to decrease PLN protein in the heart. $\mathrm{Re}$ cent studies demonstrated that certain PLN mutants increased contractility and relaxation of normal and pathological hearts when they were transferred into 
myocytes and animal hearts using adenovirus or adeno-associated vector (Minamisawa et al., 1999; Hoshijima et al., 2002; Iwanaga et al., 2004). Therefore, selective disruption of the interaction between SERCA2a and PLN is effective to prevent or reverse cardiac performance in dilated cardiomyopathy and heart failure. So far augmented SERCA2a activity has beneficial effects on the cardiac function in rodent models of heart failure. This can be a novel inotropic therapy for cardiac dysfunction, at least for a short period. However, it should be carefully evaluated whether augmented SERCA2a activity affects morbidity and mortality in human for a long period, since a null PLN mutation causes dilated cardiomyopathy in human described above (Haghighi et al., 2003).

In addition to reduced SR Ca ${ }^{2+}$ uptake, increased $\mathrm{Ca}^{2+}$ leak through RyRs is a significant component of altered $E C$ coupling in heart failure. A leak of $\mathrm{Ca}^{2+}$ from the $S R$ decreases SR $\mathrm{Ca}^{2+}$ content and release of systolic $\mathrm{Ca}^{2+}$, and it may be a trigger for arrhythmias. Moreover, altered cytosolic $\mathrm{Ca}^{2+}$ by increased $\mathrm{Ca}^{2+}$ leak may contribute to altered gene expression and myocardial remodeling. FKBPs are a good candidate to stabilize the RyR to reduce the leak of $\mathrm{Ca}^{2+}$ through RyRs. In this regard, Prestle et al. demonstrated that $\mathrm{Ca}^{2+}$ leak through RyRs was reduced in adenoviral mediated FKBP12.6 overexpressed cardiomyocytes (Prestle et al., 2001). Yao et al. recently reported that the prevention of $\mathrm{Ca}^{2+}$ leak through RyRs improved ventricular function and prevention of heart failure in a dog model, using the agent JTV519, which restores the FKBP12.6-mediated stabilization of RyR (Yano et al., 2003). JTV519 also prevented fetal ventricular arrhythmias caused by the $\mathrm{Ca}^{2+}$ leak from the RyR2 (Wehrens et al., 2004). Therefore, reducing $S R$ leak is a promising approach to improve $\mathrm{Ca}^{2+}$ cycling of the failing heart as well as arrhythmias.

More than 100 years after Ringer's discovery indicating that $\mathrm{Ca}^{2+}$ is essential for normal muscle contraction, we have been realizing that the modulation of intracellular $\mathrm{Ca}^{2+}$ concentration via manipulating the SR proteins is promising tactics to fight a monster syndrome, "heart failure".

\section{Acknowledgment}

This work was supported in part by the Ministry of Education, Science, Sports and Culture of Japan (to S.Minamisawa), the Organization for Pharmaceutical Safety and Research Grant MF-16 (to Y. Sato), the Japan Health Sciences Foundation Grant KH23106 (to $Y$. Sato), and the Research Center for Bioresource and Health (RCBH) and KOSEF (to MC Cho).

\section{References}

Baker DL, Hashimoto K, Grupp IL, Ji Y, Reed T, Loukianov E, Grupp G, Bhagwhat A, Hoit B, Walsh R, Marban E, Periasamy M. Targeted overexpression of the sarcoplasmic reticulum $\mathrm{Ca2+-ATPase}$ increases cardiac contractility in transgenic mouse hearts. Circ Res 1998;83:1205-14

Bauce B, Rampazzo A, Basso C, Bagattin A, Daliento L, Tiso N, Turrini P, Thiene G, Danieli GA, Nava A. Screening for ryanodine receptor type 2 mutations in families with effort-induced polymorphic ventricular arrhythmias and sudden death: early diagnosis of asymptomatic carriers. J Am Coll Cardiol 2002;40:341-9

Brittsan AG, Carr AN, Schmidt AG, Kranias EG. Maximal inhibition of SERCA2 $\mathrm{Ca}(2+)$ affinity by phospholamban in transgenic hearts overexpressing a non-phosphorylatable form of phospholamban. J Biol Chem 2000;275:12129-35

Caswell AH, Brandt NR, Brunschwig JP, Purkerson S Localization and partial characterization of the oligomeric disulfide-linked molecular weight 95,000 protein (triadin) which binds the ryanodine and dihydropyridine receptors in skeletal muscle triadic vesicles. Biochemistry 1991;30:750713

Chien KR. Genomic circuits and the integrative biology of cardiac diseases. Nature 2000;407:227-32

Cho MC, Rapacciuolo A, Koch WJ, Kobayashi Y, Jones LR, Rockman HA. Defective beta-adrenergic receptor signaling precedes the development of dilated cardiomyopathy in transgenic mice with calsequestrin overexpression. J Biol Chem 1999;274:22251-6

Cho MC, Choi SY, Kim YH, Kwon JS, Youn TJ, Kim DW, Hong CS, Kim DH. J Am Coll Cardiol 2003;41(Supplement): $313 \mathrm{~A}$

Chu G, Li L, Sato Y, Harrer JM, Kadambi VJ, Hoit BD, Bers $D$, Mand Kranias EG. Pentameric assembly of phospholamban facilitates inhibition of cardiac function in vivo. J Biol Chem 1998;273:33674-80

Colyer J. Phosphorylation states of phospholamban. Ann N Y Acad Sci 1998;853:79-91

Dash R, Kadambi V, Schmidt AG, Tepe NM, Biniakiewicz $D$, Gerst MJ, Canning AM, Abraham WT, Hoit BD, Liggett SB, Lorenz JN, Dorn GW, 2nd, Kranias EG. Interactions between phospholamban and beta-adrenergic drive may lead to cardiomyopathy and early mortality. Circulation 2001;103: 889-96

del Monte F, Williams E, Lebeche D, Schmidt U, Rosenzweig A, Gwathmey JK, Lewandowski ED, Hajjar RJ. Improvement in survival and cardiac metabolism after gene transfer of sarcoplasmic reticulum $\mathrm{Ca}(2+)$-ATPase in a rat model of heart failure. Circulation 2001;104:1424-9

del Monte F, Lebeche D, Guerrero JL, Tsuji T, Doye AA, Gwathmey JK, Hajjar RJ. Abrogation of ventricular arrhythmias in a model of ischemia and reperfusion by targeting myocardial calcium cycling. Proc Natl Acad Sci USA 2004; 101:5622-7

Dillmann WH. Calcium regulatory proteins and their alteration by transgenic approaches. Am J Cardiol 1999;83:89H-91H 
Eizema K, Fechner H, Bezstarosti K, Schneider-Rasp S, van der Laarse A, Wang H, Schultheiss HP, Poller WC, Lamers JM. Adenovirus-based phospholamban antisense expression as a novel approach to improve cardiac contractile dysfunction: comparison of a constitutive viral versus an endothelin-1-responsive cardiac promoter. Circulation 2000;101: 2193-9

Frank K, Kranias EG. Phospholamban and cardiac contractility. Ann Med 2000;32:572-8

Greene AL, Lalli MJ, Ji Y, Babu GJ, Grupp I, Sussman M, Periasamy $M$. Overexpression of SERCA2b in the heart leads to an increase in sarcoplasmic reticulum calcium transport function and increased cardiac contractility. J Biol Chem 2000;275:24722-7

Haghighi K, Schmidt AG, Hoit BD, Brittsan AG, Yatani A, Lester JW, Zhai J, Kimura Y, Dorn GW 2nd, MacLennan DH, Kranias EG. Superinhibition of sarcoplasmic reticulum function by phospholamban induces cardiac contractile failure. J Biol Chem 2001;276:24145-52

Haghighi K, Kolokathis K, Pater L, Lynch RA, Asahi M, Gramolini AO, Fan G, Tsiapras D, Hahn HS, Adamopoulos $S$, Liggett SB, Dorn II GW, MacLennan DH, Kremastinos DT, Kranias EG. Human phospholamban null results in lethal dilated cardiomyopathy revealing a critical difference between mouse and human. J Clin Invest 2003;111:869-876

He H, Giordano FJ, Hilal-Dandan R, Choi DJ, Rockman HA, McDonough PM, Bluhm WF, Meyer M, Sayen MR, Swanson $E$, Dillmann WH. Overexpression of the rat sarcoplasmic reticulum $\mathrm{Ca} 2+$ ATPase gene in the heart of transgenic mice accelerates calcium transients and cardiac relaxation. J Clin Invest 1997:100:380-9

He H, Meyer M, Martin JL, McDonough PM, Ho P, Lou X, Lew WY, Hilal-Dandan R, Dillmann WH. Effects of mutant and antisense RNA of phospholamban on SR $\mathrm{Ca}(2+)-$ ATPase activity and cardiac myocyte contractility. Circulation 1999;100:974-80

Hong CS, Kwak YG, Ji JH, Chae SW, Kim do H. Molecular cloning and characterization of mouse cardiac junctate isoforms. Biochem Biophys Res Commun 2001;289:882-7

Hong CS, Cho MC, Kwak YG, Song CH, Lee YH, Lim JS, Kwon YK, Chae SW, Kim do H. Cardiac remodeling and atrial fibrillation in transgenic mice overexpressing junctin. Faseb J 2002;16:1310-2

Hoshijima M, Ikeda $Y$, Iwanaga $Y$, Minamisawa S, Date MO, Gu Y, Iwatate M, Li M, Wang L, Wilson JM, Wang Y, Ross $\mathrm{J} \mathrm{Jr}$, Chien KR. Chronic suppression of heart-failure progression by a pseudophosphorylated mutant of phospholamban via in vivo cardiac rAAV gene delivery. Nat Med 2002;8:864-71

Houser SR, Piacentino V 3rd, Weisser J. Abnormalities of calcium cycling in the hypertrophied and failing heart. $\mathrm{J}$ Mol Cell Cardiol 2000;32:1595-607

Ito K, Komazaki S, Sasamoto K, Yoshida M, Nishi M, Kitamura K, Takeshima H. Deficiency of triad junction and contraction in mutant skeletal muscle lacking junctophilin type 1. J Cell Biol 2001;154:1059-67

Iwanaga $Y$, Hoshijima M, Gu Y, Iwatate M, Dieterle T, Ikeda $\mathrm{Y}$, Date MO, Chrast J, Matsuzaki M, Peterson KL, Chien
KR, Ross J Jr. Chronic phospholamban inhibition prevents progressive cardiac dysfunction and pathological remodeling after infarction in rats. J Clin Invest 2004;113:727-36

Ji Y, Lalli MJ, Babu GJ, Xu Y, Kirkpatrick DL, Liu LH, Chiamvimonvat $N$, Walsh RA, Shull GE, Periasamy M. Disruption of a single copy of the SERCA2 gene results in altered $\mathrm{Ca} 2+$ homeostasis and cardiomyocyte function. J Biol Chem 2000;275:38073-80

Jones LR, Zhang L, Sanborn K, Jorgensen AOand Kelley, $\mathrm{J}$. Purification, primary structure, and immunological characterization of the $26-\mathrm{kDa}$ calsequestrin binding protein (junctin) from cardiac junctional sarcoplasmic reticulum. J Biol Chem 1995;270:30787-96

Jones LR, Suzuki YJ, Wang W, Kobayashi YM, Ramesh V, Franzini-Armstrong C, Cleemann Land Morad M. Regulation of $\mathrm{Ca} 2+$ signaling in transgenic mouse cardiac myocytes overexpressing calsequestrin. J Clin Invest 1998;101:138593

Kadambi VJ, Ponniah S, Harrer JM, Hoit BD, Dorn GW 2nd, Walsh RA, Kranias EG. Cardiac-specific overexpression of phospholamban alters calcium kinetics and resultant cardiomyocyte mechanics in transgenic mice. J Clin Invest 1996; 97:533-9

Kadambi VJ, Kranias EG. Genetically engineered mice: model systems for left ventricular failure. J Card Fail 1998; 4:349-61

Kirchhefer U, Neumann J, Bers DM, Buchwalow IB, Fabritz L, Hanske G, Justus I, Riemann B, Schmitz W, Jones LR. Impaired relaxation in transgenic mice overexpressing junctin. Cardiovasc Res 2003;59:369-79

Kirchhefer U, Neumann J, Baba HA, Begrow F, Kobayashi YM, Reinke U, Schmitz W, Jones LR. Cardiac hypertrophy and impaired relaxation in transgenic mice overexpressing triadin 1. J Biol Chem 2001;276:4142-9.

Komazaki S, Nishi M, Takeshima H. Abnormal junctional membrane structures in cardiac myocytes expressing ectopic junctophilin type 1. FEBS Lett 2003;542:69-73.

Lahat $\mathrm{H}$, Pras $\mathrm{E}$, Olender $\mathrm{T}$, Avidan N, Ben-Asher E, Man $O$, Levy-Nissenbaum $E$, Khoury A, Lorber A, Goldman B, Lancet D, Eldar M. A missense mutation in a highly conserved region of CASQ2 is associated with autosomal recessive catecholamine-induced polymorphic ventricular tachycardia in Bedouin families from Israel. Am J Hum Genet 2001;69:1378-84

Lahat $\mathrm{H}$, Pras E, Eldar M. RYR2 and CASQ2 mutations in patients suffering from catecholaminergic polymorphic ventricular tachycardia. Circulation 2003;107, e29; author reply e29.

Laitinen PJ, Brown KM, Piippo K, Swan H, Devaney JM, Brahmbhatt $B$, Donarum EA, Marino M, Tiso N, Viitasalo M, Toivonen L, Stephan DA, Kontula K. Mutations of the cardiac ryanodine receptor (RyR2) gene in familial polymorphic ventricular tachycardia. Circulation 2001;103:485-90

Leberer E, Timms BG, Campbell KP, MacLennan DH. Purification, calcium binding properties, and ultrastructural localization of the 53,000 - and 160,000 (sarcalumenin)-dalton glycoproteins of the sarcoplasmic reticulum. J Biol Chem 1990;265:10118-24 
Loukianov E, Ji Y, Grupp IL, Kirkpatrick DL, Baker DL, Loukianova T, Grupp G, Lytton J, Walsh RA, Periasamy M. Enhanced myocardial contractility and increased $\mathrm{Ca} 2+$ transport function in transgenic hearts expressing the fast-twitch skeletal muscle sarcoplasmic reticulum Ca2+-ATPase. Circ Res 1998;83:889-97

Luo W, Grupp IL, Harrer J, Ponniah S, Grupp G, Duffy JJ, Doetschman T, Kranias EG. Targeted ablation of the phospholamban gene is associated with markedly enhanced myocardial contractility and loss of beta-agonist stimulation. Circ Res 1994;75:401-9

Marks AR, Marx SO, Reiken S. Regulation of ryanodine receptors via macromolecular complexes: a novel role for leucine/isoleucine zippers. Trends Cardiovasc Med 2002a;12: 166-70

Marks AR, Priori S, Memmi M, Kontula K, Laitinen PJ. Involvement of the cardiac ryanodine receptor/calcium release channel in catecholaminergic polymorphic ventricular tachycardia. J Cell Physiol 2002b;190:1-6

Martin DW. High efficiency $\mathrm{Ca} 2+$ transport by the sarcoplasmic reticulum $\mathrm{Ca} 2(+)$-ATPase in the absence of the 53-kilodalton glycoprotein. J Biol Chem 1990;265:20946-51

Marx SO, Reiken S, Hisamatsu Y, Jayaraman T, Burkhoff $D$, Rosemblit N, Marks AR. PKA phosphorylation dissociates FKBP12.6 from the calcium release channel (ryanodine receptor): defective regulation in failing hearts. Cell 2000;101: 365-76

Meyers MB, Fischer A, Sun YJ, Lopes CM, Rohacs T, Nakamura TY, Zhou YY, Lee PC, Altschuld RA, McCune SA, Coetzee WA, Fishman GI. Sorcin regulates excitation-contraction coupling in the heart. J Biol Chem 2003;278: 28865-71

Minamisawa S, Hoshijima M, Chu G, Ward CA, Frank K, Gu Y, Martone ME, Wang Y, Ross J Jr, Kranias EG, Giles WR, Chien KR. Chronic phospholamban-sarcoplasmic reticulum calcium ATPase interaction is the critical calcium cycling defect in dilated cardiomyopathy. Cell 1999;99:313-22

Minamisawa S, Sato $Y$, Tatsuguchi $Y$, Fujino T, Imamura $S$, Uetsuka Y, Nakazawa M, Matsuoka R. Mutation of the phospholanbam promoter associated with hypertrophic cardiomyopathy. Biochem Biophys Res Commun 2003a

Minamisawa S, Wang $Y$, Chen J, Ishikawa $Y$, Chien KR, Matsuoka R. Atrial-chamber specific expression of sarcolipin is regulated during development and hypertrophic remodeling. J Biol Chem 2003b;278:9570-9575

Miyamoto MI, del Monte F, Schmidt U, DiSalvo TS, Kang ZB, Matsui T, Guerrero JL, Gwathmey JK, Rosenzweig A, Hajjar RJ. Adenoviral gene transfer of SERCA2a improves left-ventricular function in aortic-banded rats in transition to heart failure. Proc Natl Acad Sci USA 2000;97:793-8

Muller FU, Kirchhefer U, Begrow F, Reinke U, Neumann J, Schmitz W. Junctional sarcoplasmic reticulum transmembrane proteins in the heart. Basic Res Cardiol 2002;97 Suppl $1: 152-5$

Nakayama H, Otsu K, Yamaguchi O, Nishida K, Date MO, Hongo K, Kusakari Y, Toyofuku T, Hikoso S, Kashiwase K, Takeda T, Matsumura Y, Kurihara S, Hori M, Tada M. Cardiac-specific overexpression of a high $\mathrm{Ca} 2+$ affinity mutant of SERCA2a attenuates in vivo pressure overload cardiac hypertrophy. Faseb J 2003;17:61-3

Odermatt A, Becker S, Khanna VK, Kurzydlowski K, Leisner $E$, Pette $D$, MacLennan DH. Sarcolipin regulates the activity of SERCA1, the fast-twitch skeletal muscle sarcoplasmic reticulum Ca2+-ATPase. J Biol Chem 1998;273:12360-9

Olson EN, Williams RS. Calcineurin signaling and muscle remodeling. Cell 2000;101:689-92

Periasamy M, Reed TD, Liu LH, Ji Y, Loukianov E, Paul RJ, Nieman ML, Riddle T, Duffy JJ, Doetschman T, Lorenz JN, Shull GE. Impaired cardiac performance in heterozygous mice with a null mutation in the sarco(endo)plasmic reticulum Ca2+-ATPase isoform 2 (SERCA2) gene. J Biol Chem 1999; 274:2556-62

Periasamy $M$, Huke S. SERCA pump level is a critical determinant of $\mathrm{Ca}(2+)$ homeostasis and cardiac contractility. J Mol Cell Cardiol 2001;33:1053-63

Postma AV, Denjoy I, Hoorntje TM, Lupoglazoff JM, Da Costa A, Sebillon P, Mannens MM, Wilde AA, Guicheney $P$. Absence of calsequestrin 2 causes severe forms of catecholaminergic polymorphic ventricular tachycardia. Circ Res 2002;91:e21-6.

Prestle J, Janssen PM, Janssen AP, Zeitz O, Lehnart SE, Bruce L, Smith GL, Hasenfuss G. Overexpression of FK506binding protein FKBP12.6 in cardiomyocytes reduces ryanodine receptor-mediated $\mathrm{Ca}(2+)$ leak from the sarcoplasmic reticulum and increases contractility. Circ Res 2001;88:18894

Priori SG, Napolitano C, Memmi M, Colombi B, Drago F, Gasparini M, DeSimone L, Coltorti F, Bloise R, Keegan R, Cruz Filho FE, Vignati G, Benatar A, DeLogu A. Clinical and molecular characterization of patients with catecholaminergic polymorphic ventricular tachycardia. Circulation 2002;106:6974

Sande JB, Sjaastad I, Hoen IB, Bokenes J, Tonnessen T, Holt E, Lunde PK, Christensen G. Reduced level of serine (16) phosphorylated phospholamban in the failing rat myocardium: a major contributor to reduced SERCA2 activity. Cardiovasc Res 2002;53:382-91

Sato $Y$, Ferguson DG, Sako H, Dorn GW 2nd, Kadambi VJ, Yatani A, Hoit BD, Walsh RA, Kranias EG. Cardiac-specific overexpression of mouse cardiac calsequestrin is associated with depressed cardiovascular function and hypertrophy in transgenic mice. J Biol Chem 1998;273:28470-7

Schmidt AG, Zhai J, Carr AN, Gerst MJ, Lorenz JN, Pollesello P, Annila A, Hoit BD, Kranias EG. Structural and functional implications of the phospholamban hinge domain: impaired SR Ca2+ uptake as a primary cause of heart failure. Cardiovasc Res 2002;56:248-59

Schmidt U, Hajjar RJ, Kim CS, Lebeche D, Doye AA, Gwathmey JK. Human heart failure: cAMP stimulation of SR $\mathrm{Ca}(2+)$-ATPase activity and phosphorylation level of phospholamban. Am J Physiol 1999;277:H474-80

Schmitt JP, Kamisago M, Asahi M, Li GH, Ahmad F, Mende U, Kranias EG, MacLennan DH, Seidman JG, Seidman CE. Dilated cardiomyopathy and heart failure caused by a mutation in phospholamban. Science 2003;299:1410-3 
Scoote M, Williams AJ. The cardiac ryanodine receptor (calcium release channel): emerging role in heart failure and arrhythmia pathogenesis. Cardiovasc Res 2002;56:359-72

Seidman JG, Seidman C. The genetic basis for cardiomyopathy: from mutation identification to mechanistic paradigms. Cell 2001;104:557-67

Shou W, Aghdasi B, Armstrong DL, Guo Q, Bao S, Charng MJ, Mathews LM, Schneider MD, Hamilton SL, Matzuk MM. Cardiac defects and altered ryanodine receptor function in mice lacking FKBP12. Nature 1998;391:489-92

Sitsapesan R, Williams AJ. Regulation of current flow through ryanodine receptors by luminal $\mathrm{Ca} 2+$. J Membr Biol 1997;159:179-85

Takeshima H, Komazaki S, Hirose K, Nishi M, Noda T, lino $M$. Embryonic lethality and abnormal cardiac myocytes in mice lacking ryanodine receptor type 2. Embo J 1998;17: 3309-16

Takeshima H, Komazaki S, Nishi M, lino M, Kangawa K. Junctophilins: a novel family of junctional membrane complex proteins. Mol Cell 2000;6:11-22

Tiso $N$, Stephan DA, Nava A, Bagattin A, Devaney JM, Stanchi $F$, Larderet G, Brahmbhatt B, Brown K, Bauce B, Muriago M, Basso C, Thiene G, Danieli GA, Rampazzo A. Identification of mutations in the cardiac ryanodine receptor gene in families affected with arrhythmogenic right ventricular cardiomyopathy type 2 (ARVD2). Hum Mol Genet 2001;10: 189-94

Treves S, Feriotto G, Moccagatta L, Gambari R, Zorzato F. Molecular cloning, expression, functional characterization, chromosomal localization, and gene structure of junctate, a novel integral calcium binding protein of sarco(endo)plasmic reticulum membrane. J Biol Chem 2000;275:39555-68

Ver Heyen M, Heymans S, Antoons G, Reed T, Periasamy M, Awede B, Lebacq J, Vangheluwe P, Dewerchin M, Collen $D$, Sipido K, Carmeliet P, Wuytack F. Replacement of the muscle-specific sarcoplasmic reticulum $\mathrm{Ca}(2+)$-ATPase isoform SERCA2a by the nonmuscle SERCA2b homologue causes mild concentric hypertrophy and impairs contractionrelaxation of the heart. Circ Res 2001;89:838-46

Wehrens XH, Lehnart SE, Huang F, Vest JA, Reiken SR, Mohler PJ, Sun J, Guatimosim S, Song LS, Rosemblit N,
D'Armiento JM, Napolitano C, Memmi M, Priori SG, Lederer WJ, Marks AR. FKBP12.6 deficiency and defective calcium release channel (ryanodine receptor) function linked to exercise-induced sudden cardiac death. Cell 2003;113:829-40

Wehrens XH, Lehnart SE, Reiken SR, Deng SX, Vest JA, Cervantes D, Coromilas J, Landry DW, Marks AR. Protection from cardiac arrhythmia through ryanodine receptor-stabilizing protein calstabin2. Science 2004;304:292-6

Wilkins BJ, Molkentin JD. Calcineurin and cardiac hypertrophy: where have we been? Where are we going? J Physiol 2002;541:1-8

Xin HB, Senbonmatsu T, Cheng DS, Wang YX, Copello JA, Ji GJ, Collier ML, Deng KY, Jeyakumar LH, Magnuson MA, Inagami $\mathrm{T}$, Kotlikoff $\mathrm{MI}$, Fleischer $\mathrm{S}$. Oestrogen protects FKBP12.6 null mice from cardiac hypertrophy. Nature 2002;416:334-8

Yano M, Ono K, Ohkusa T, Suetsugu M, Kohno M, Hisaoka T, Kobayashi S, Hisamatsu Y, Yamamoto T, Noguchi N, Takasawa S, Okamoto $\mathrm{H}$, Matsuzaki M. Altered stoichiometry of FKBP12.6 versus ryanodine receptor as a cause of abnormal $\mathrm{Ca}(2+)$ leak through ryanodine receptor in heart failure. Circulation 2000;102:2131-6

Yano M, Kobayashi S, Kohno M, Doi M, Tokuhisa T, Okuda $\mathrm{S}$, Suetsugu M, Hisaoka T, Obayashi M, Ohkusa T, Matsuzaki M. FKBP12.6-mediated stabilization of calciumrelease channel (ryanodine receptor) as a novel therapeutic strategy against heart failure. Circulation 2003;107:477-84

Zhang L, Kelley J, Schmeisser G, Kobayashi YM, Jones LR. Complex formation between junctin, triadin, calsequestrin, and the ryanodine receptor. Proteins of the cardiac junctional sarcoplasmic reticulum membrane. J Biol Chem 1997;272: 23389-97

Zhang L, Franzini-Armstrong C, Ramesh V, Jones LR. Structural alterations in cardiac calcium release units resulting from overexpression of junctin. J Mol Cell Cardiol 2001;33: 233-47

Zvaritch E, Backx PH, Jirik F, Kimura $Y$, de Leon S, Schmidt AG, Hoit BD, Lester JW, Kranias EG, MacLennan DH. The transgenic expression of highly inhibitory monomeric forms of phospholamban in mouse heart impairs cardiac contractility. J Biol Chem 2000;275:14985-91 